\title{
Detection of genotoxic effect of potassium permanganate by using in vitro micronucleus
}

\section{assay}

\section{Potasyum permanganatın genotoksik etkisinin in vitro mikronükleus testi ile saptanması}

\author{
Gökhan Gencer ${ }^{1}$, Levent Özdemir ${ }^{2}$, Öztüirk Özdemir ${ }^{3}$
}

${ }^{1}$ Sivas Cumhuriyet University, Health Sciences Institute, Sivas, Turkey

${ }^{2}$ Sivas Cumhuriyet University, Faculty of Medicine, Public Health Department, Sivas, Turkey

${ }^{3}$ Çanakkale Onsekiz Mart University, Faculty of Medicine, Department of Medical Genetics, Çanakkale, Turkey

Corresponding author: Levent Özdemir, MD, Bursa Uludağ University, Faculty of Medicine, Public Health Department, Bursa, Turkey

E-mail: leventozdemir@uludag.edu.tr

Received/Accepted: December 31, 2019 /May 11, 2020

Conflict of interest: There is not a conflict of interest.

\section{SUMMARY}

Objective: Hydrogen peroxide is a bleaching agent accepted as safe for environment and used for producing cotton fabrics. This process requires alkaline medium, stabilizer and high temperature. For this purpose, it is used extensively in the textile industry. Potassium permanganate is a widely used agent in our country as it is easier to obtain compared to other oxidizing agents. In this study, we investigated whether occupational exposure to potassium permanganate causes genotoxic effect or not.

Method: This cross-sectional study was carried out in a denim factory located in the Organized Industrial Zone in Sivas. The total number of employees was 600 in the factory including 50 workers in the office and 550 workers in the production department.

The study group was consisted of 32 healthy males, non-smokers, without chronic diseases and infections. They had been working at least 2 years in denim bleaching unit. The control group was consisted of 30 healthy male volunteers, at similar age, non-smokers, working in administrative or desk jobs in the same factory, with little or no risk of chemical exposure. Workers who had an infection in the last month and who were on medication were excluded from the study. In Vitro Micronucleus Test was used to determine the genotoxic effect of potassium permanganate. The venous blood samples taken from the workers and controls was cultured in laboratory conditions according to Fenech's method with minor modifications. Evaluation of slides was carried out according to Fenech's microscopic survey criteria at $\times 1000$ magnification. The frequencies of the total number of micronuclei in the lymphocytes (MNL) and bi-nucleated cells with the micronuclei (BNMN) were determined. In addition, to determine the frequencies of nucleoplasmic bridges (NPBs) and nuclear buds (NBUDs), 1000 nucleated cells with well-preserved cytoplasm were also evaluated. Student's T-test was used for statistical evaluation.

Results: When groups were compared, the micronucleus frequency was detected as about twice high in study group. Statistically significant difference was detected between the study and control group $(\mathrm{p}<0.05)$. The nuclear bud frequency was significantly higher in study groups than in controls $(\mathrm{p}<0.05)$. Although the number of nucleoplasmic bridges were higher in study group, this difference was not statistically significant ( $>0.05)$.

\section{Gökhan Gencer \\ Levent Özdemir \\ Öztürk Özdemir}

ORCID IDs of the authors: G.G. 0000-0001-7727-5676 L.Ö. 0000-0002-4330-8334 Ö.Ö. 0000-0003-1057-3235 
Conclusions: Indicators of genotoxic effect were higher in the group with potassium permanganate exposure than the control group. High micronucleus and nuclear bud frequencies in the study group may be indicative of genotoxicity. It may be thought that clastogenic and mutagenic risk increases for employees.

Keywords: Potassium permanganate, micronucleus, nucleoplasmic bridge, nuclear bud, genotoxicity

\section{ÖZET}

Amaç: Hidrojen peroksit, çevre için güvenli olduğu kabul edilen ve pamuklu kumaşların üretiminde kullanılan bir ağartma maddesidir. Bu işlem alkali ortam, dengeleyici ve yüksek sicaklık gerektirir. Bu amaçla tekstil endüstrisinde yaygın olarak kullanılmaktadır. Potasyum permanganat, diğer oksitleyici ajanlara kıyasla elde edilmesi daha kolay olduğu için ülkemizde yaygın olarak kullanılan bir ajandır. Bu çalışmada, potasyum permanganata mesleki maruziyetin genotoksik etkiye neden olup olmadığını araştırdık.

Yöntem: Bu kesitsel çalışma Sivas Organize Sanayi Bölgesi'nde yer alan bir kot fabrikasında gerçekleştirilmiştir. Ofis bölümünde 50, üretim departmanında 550 işçi olmak üzere fabrikada toplam çalışan sayısı 600'dür.

Çalışma grubu kronik hastalıkları ve enfeksiyonu olmayan, sigara içmeyen 32 sağlıklı erkek çalışandan oluşturuldu. Kot ağartma ünitesinde en az 2 yıl çalışanlar çalışmaya dahil edildi. Kontrol grubu, benzer yaşta sigara içmeyen, aynı fabrikada idari veya masa başı işlerde çalışan, kimyasal maruziyet riski çok az olan veya hiç olmayan 30 sağlıklı erkek gönüllüden oluşmaktaydı. Son bir ayda enfeksiyon geçiren ve ilaç tedavisi alan işçiler çalışma dışı bırakıldı. Genotoksik etkinin saptanması için İn Vitro Mikronükleus Testi kullanıldı. İşçilerden ve kontrollerden alınan venöz kan örnekleri laboratuvar koşullarında Fenech'in yöntemine göre kültürlendi. Preparatların değerlendirilmesi Fenech' in $\times 1000$ büyütmede mikroskopik inceleme kriterlerine göre yapıldı. Lenfositlerde ve binükleotid hücrelerde mikronükleus ile toplam mikronükleus sayısı belirlendi. Ek olarak, nükleoplazmik köprülerin ve nükleer tomurcukların frekanslarını belirlemek için iyi korunmuş sitoplazmaya sahip 1000 nükleotid hücre değerlendirildi.

Bulgular: Mikronükleus frekansı çalışma grubunda yaklaşık iki kat yüksek bulundu. Çalışma ve kontrol grubu arasındaki fark istatistiksel olarak anlamlıydı $(\mathrm{p}<0.05)$. Nükleer tomurcuk sıklığı çalışma gruplarında kontrol grubuna göre anlamlı olarak yüksekti $(\mathrm{p}<0.05)$. Her ne kadar çalışma grubunda nükleoplazmik köprü sayısı daha yüksek olsa da, bu fark istatistiksel olarak anlamlı değildi $(\mathrm{p}>0.05)$.

Sonuç: Genotoksik etki göstergeleri potasyum permanganat maruziyeti olan grupta kontrol grubuna göre daha yüksekti. Çalışma grubundaki yüksek mikronükleus ve nükleer tomurcuk frekansları, genotoksisiteyi gösterebilir. Çalışanlar için klastojenik ve mutajenik riskin arttığı düșünülebilir.

Anahtar sözcükler: Potasyum permanganat, mikronükleus, nükleoplazmik köprü, nükleer tomurcuk, genotoksisite

\section{INTRODUCTION}

In the last century, the use of chemicals has increased rapidly. Chemicals that contributed to prolonging human life, used for cleaning water and foodstuffs from pathogens are important for a healthy life. However, chemicals have the potential harm effect to human health and the environment.

Hydrogen peroxide is a bleaching agent accepted as safe for environment and used for producing cotton fabrics. This process requires alkaline medium, stabilizer and high temperature ${ }^{1}$. For this purpose it is used extensively in the textile industry ${ }^{2}$. Potassium permanganate is a widely used agent in our country as it is easier to obtain compared to other oxidizing agents ${ }^{3}$.

The uncontrolled use of chemicals may lead to hazardous effect on the environment and human health. Toxicology is a science that interested in biological effect of exposure to chemicals ${ }^{4}$. Molecular biology investigates the effects of chemical substances at the molecular level in recent years. Especially genotoxicity studies in this area are increasing. Short-term genotoxicity tests is used for determining whether a chemical substance is being genotoxic. Sister chromatid exchange (SCE) ${ }^{5}$ chromosome aberration (CA) ${ }^{6}$ and micronucleus (MN) assay ${ }^{7}$ are methods that evaluating genotoxicity. For assessing the hazardous effects of chemicals plenty of studies have been performed using cytogenetic methods on micronucleus, chromosome aberrations and sister chromatid exchange ${ }^{8-10}$. The first application of this method was performed by Countryman and Heddle (1976) ${ }^{11}$. Fenech and Morley (1985) then improved this method as the cytokinesis-block micronucleus assay $(\mathrm{CBMN})^{12}$. The CBMN assay has been suggested as a comprehensive method for measuring chromosome breakage, chromosome loss, nondisjunction, necrosis, apoptosis and cytostasis ${ }^{13}$. 
In this study, we investigated whether occupational exposure to potassium permanganate causes genotoxic effect. For this purpose, we evaluated micronucleus, nucleoplasmic bridges and nuclear bud formation which are genotoxicity biomarkers in human peripheral lymphocytes.

\section{MATERIAL AND METHODS}

This cross-sectional study was carried out in a denim factory located in the Organized Industrial
Zone in Sivas. The factory has a production area of 12.250 square meters. The factory has cutting, sewing and bleaching sections respectively. The trousers are treated with potassium permanganate in the bleaching section (Figure 1). The treated jeans are washed in the washing section. Afterwards, the jeans passing through the last checks are packed in the ironing and packaging sections. Bleaching section has a separate ventilation, also it has no direct connection with other parts of the sections.

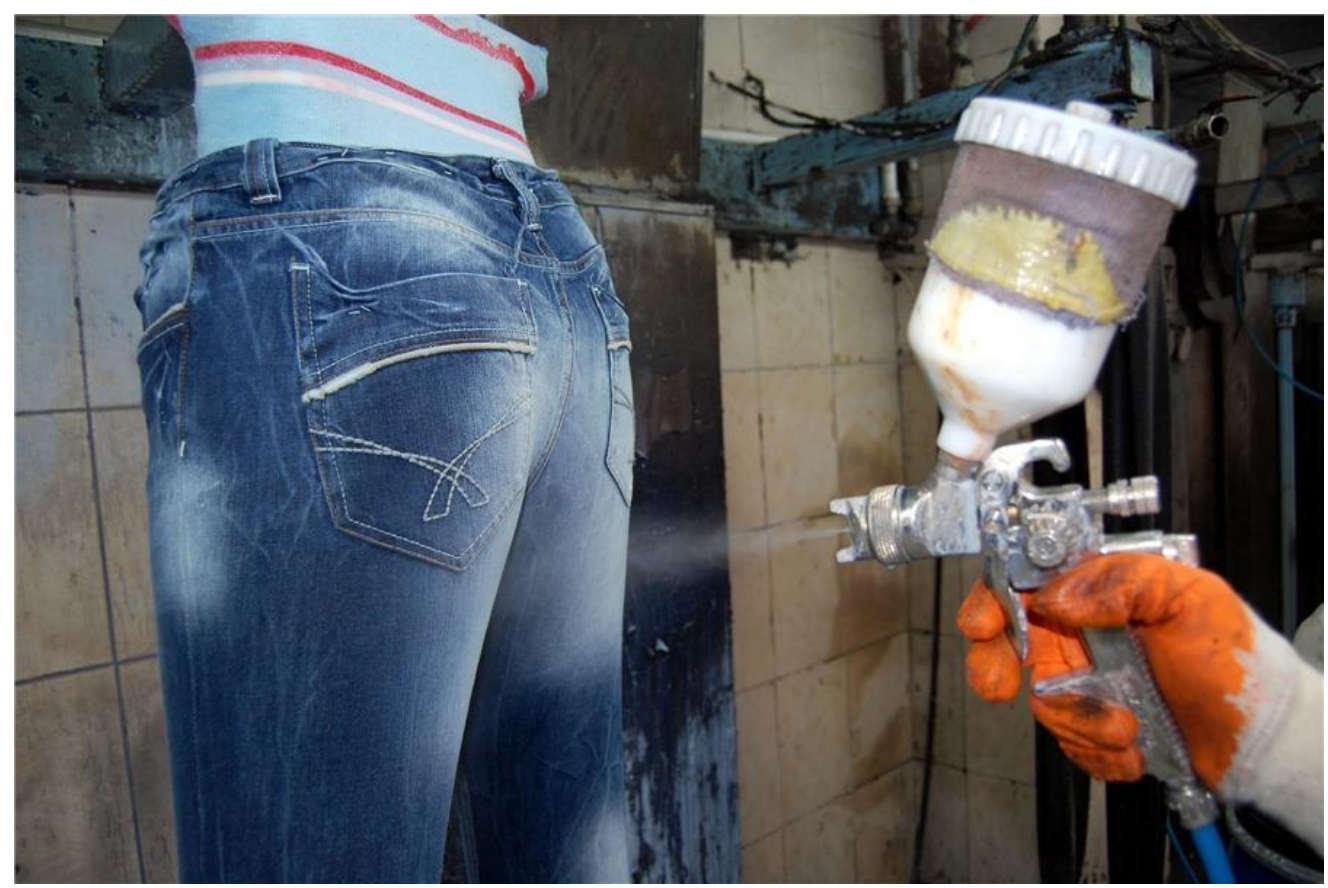

Figure 1: Implementation of potassium permanganate

The total number of employees was 600 in the factory including 50 workers in the office and 550 workers in the production department. The study group was consisted of 32 healthy males, nonsmokers, having not chronic diseases and infections. They had been worked at least 2 years in denim bleaching unit. The control group was consisted of 30 healthy male volunteers, at similar age, non-smokers, working in administrative or desk jobs in the same factory, with little or no risk of chemical exposure. Workers who had an infection in the last month and who were on medication were excluded from the study.

In Vitro Micronucleus Test was used to determine the genotoxic effect of potassium permanganate. Venous blood samples were taken from the antecubital fossa. Blood was cultured in laboratory conditions according to Fenech's method with minor modifications ${ }^{12}$. The duration of the lymphocyte culture incubation was $68 \mathrm{~h}$ at $37^{\circ} \mathrm{C}$. At the end of this period the cells were fixed. At this stage, $0.075 \mathrm{M} \mathrm{KCl}$ was used as hypotonic solution and acetic acid methanol mixture $(1: 7 \mathrm{v} / \mathrm{v})$ as fixative. Slides were stained with Giemsa for microscopic analysis. Evaluation of slides was carried out according to Fenech's microscopic survey criteria at $\times 1000$ magnification ${ }^{14}$. For this study, 1000 nucleated cells were counted for each individual. The frequencies of the total number of micronuclei in the lymphocytes (MNL) and binucleated cells with the micronuclei (BNMN) were determined. In addition, to determine the frequencies of nucleoplasmic bridges (NPBs) and nuclear buds (NBUDs), 1000 nucleated cells with well-preserved cytoplasm were also evaluated. Student's T-test was used for statistical evaluation. 


\section{RESULTS}

Presented results show MN cell profiles in Potassium permanganate exposed textile workers and non-exposed healthy control groups. Increased micronuclei and nuclear bud profiles were detected after statistical analysis of the current results (Table 1).

Table 1: The means of the genotoxicity parameters in study and control groups

\begin{tabular}{|l|c|c|c|}
\hline \multirow{2}{*}{\multicolumn{1}{|c|}{ PARAMETERS }} & \multicolumn{3}{|c|}{ GROUPS } \\
\cline { 2 - 3 } & $\begin{array}{c}\text { Study group } \\
(\mathbf{n}=\mathbf{3 2})\end{array}$ & $\begin{array}{c}\text { Control } \\
(\mathbf{n}=\mathbf{3 0})\end{array}$ & \multirow{2}{*}{ Test Statistics } \\
\cline { 2 - 3 } & $\mathrm{X} \pm \mathrm{SEM}$ & $\mathrm{X} \pm \mathrm{SEM}$ & $\mathrm{p}>0.05$ \\
\hline Age & $31.5 \pm 1.2$ & $30.5 \pm 0.8$ & $\mathrm{p}<0.05$ \\
\hline Micronucleus* & $30.0 \pm 3.0$ & $17.8 \pm 1.4$ & $\mathrm{p}<0.05$ \\
\hline Nuclear Bud* & $19.3 \pm 1.9$ & $10.2 \pm 0.8$ & $\mathrm{p}>0.05$ \\
\hline Nucleoplasmic Bridge & $3.9 \pm 0.6$ & $2.9 \pm 0.7$ & \\
*: Significant & & & \\
\end{tabular}

The means of age were detected in the control and study group as $30.5 \pm 0.8$ and $31.5 \pm 1.2$ respectively. In terms of mean age between the study and control group was not detected statistically significant difference ( $p>0.05)$.

There was no statistically significant relationship in the correlation analysis between micronucleus, nuclear bud, nucleoplasmic bridge number and age $(\mathrm{p}>0.05)$.

When compared groups, the micronucleus frequency was detected as about twice high in study group. Statistically significant difference was detected between the study and control group $(\mathrm{p}<0.05)$

The nuclear bud frequency was significantly higher in study group than control $(\mathrm{p}<0.05)$. Although the number of nucleoplasmic bridges frequency was higher in study group, this difference was not statistically significant $(\mathrm{p}>0.05)$.

\section{DISCUSSION}

People are faced with mutagenic and carcinogenic effects of genotoxic agents in the workplace or in daily life. Therefore, it is important to investigate the effects of mutagenic and carcinogenic compounds 15,16. The aim of this study is to investigate the effect of potassium permanganate on DNA stability.

In many studies, genotoxic effects of various chemicals were investigated using micronucleus method. In Lovreglio study chromosomal aberrations and micronucleus formations were investigated in workers exposed to low levels of benzene. They reported that there was no difference between the study and control groups in terms of chromosomal aberration and micronucleus ${ }^{17}$.

White et al. reported that exposure to perchlorethylene, a substance used in the Dry Cleaning sector, causes micronucleus formation in human peripheral lymphocytes ${ }^{18}$.

In Yildirım's study the micronucleus frequency have investigated in buccal mucosal epithelium in printing press workers. According to result of the study the micronucleus and binuclear cell ratios were increased in the oral mucosa cells in study population ${ }^{19}$.

Mahmut et al. reported that micronuclei and NBUDs frequencies were significantly higher in farmers exposed to pesticides in Çanakkale. In Mahmut's study, although the frequency of NPB of the farmers was higher than the controls, there was no statistical difference ${ }^{20}$. These findings of the Mahmut's study are consistent with our study. In the study of Kültigin et al., it was reported that the frequency of micronucleus in the epithelial cells in the buccal mucosa increased in smokers 21 . Although smoking has been proven to be carcinogenic, its effects on micronucleus frequency are not clear in genotoxicity studies. In Bonass's study heavy smokers were the only group showing a significant increase in genotoxic damage measured by the micronucleus assay in lymphocytes ${ }^{22}$. In our study, the effect of smoking on micronucleus, nucleoplasmic bridge and nuclear bud formation was limited since there were no smokers in both groups. We think that limiting the selection of participants strongly demonstrates the genotoxic effect of potassium permanganate.

In many studies have been reported that the number of $\mathrm{MN}$ increases with age ${ }^{23,24}$. In our study there 
was no significant difference between the groups in terms of age. In addition, we couldn't find any statistically significant relationship between age and genotoxicity parameters in correlation analysis. In our study, we think that this result is due to the low mean age and narrow age distribution of the participants.

Potassium permanganate is an oxidizing agent and has disinfectant, deodorizing and firming properties. The literature on the genotoxic effect of potassium permanganate is limited. There are very few studies investigating the long-term effects of chronic occupational exposure. De Meo et al. investigated the genotoxic effect of potassium permanganate, manganese sulfate and manganese chloride in their study. They reported that only manganese chloride initiates dose response-related DNA damage in human lymphocytes ${ }^{25}$. Kaya et al. reported that potassium bromate used as flour bleaching agent increases micronucleus formation in peripheral blood lymphocytes ${ }^{26}$. In Lima's study genotoxic effects were observed only in high doses of manganese treatment in human lymphocyte cultures ${ }^{27}$. Baron and Moss reported that caustic burns occurred in an 18-month-old baby sitting on a potassium permanganate tablet used in children due to its antiseptic properties ${ }^{28}$. In 1997, Ong et al. reported that there were two deaths in the last 12 years as a result of accidental ingestion of potassium permanganate tablets ${ }^{29}$.

We detected the count of micronucleus, nuclear bridge and nuclear bud in peripheral lymphocytes to determine the genotoxic effect of potassium permanganate in our study. Indicators of genotoxic effect were higher in the group with potassium permanganate exposure than the control group. High micronucleus and nuclear bud frequencies in the study group may be indicative of genotoxicity. It may be thought that clastogenic and mutagenic risk increases for employees. Further studies are needed to determine the genotoxic effect due to exposure time and the amount of potassium permanganate.

Studies in recent years have shown that; micronucleus test, which is considered as an indirect indicator of chromosomal irregularities both numerically and structurally, can be safely used in studies to determine the cytogenetic effects of physical and chemical agents.

Furthermore, training programs should be organized for the employees in this sector and they should be informed about the occupational risks. Providing occupational safety conditions, paying attention to periodic controls of employees to prevent diseases, controlling the workplace environment to minimize risks, and taking preventive measures are very important for workers' health. Conducting larger and multicenter studies on this subject will contribute to the prevention of important health problems in the textile industry in the future.

\section{Study Regarding Limitations;}

Toxic concentrations in the workplace should be measured. Measurements should be made during the most active working period and when evaporation is highest. However, in our study, there was no measurement value related to this.

Other factors were not under control except for drug use, infection and smoking that caused micronucleus formation.

In addition, for a clearer assessment of chemical exposure, the concentration of potassium permanganate in the workplace and the biological monitoring of workers had to be carried out together.

\section{CONCLUSION}

Although this is a preliminary study, our results allowed to recognize that individuals who exposed to potassium permanganate for a long time without significant protection are at very serious risk. Workers could be considered as a susceptible groups and should be checked periodically. Results need to be supported by studies involving a large sample size.

\section{Competing interests}

All authors declare that they have no competing interests.

\section{Authors' contributions}

- G.G. and L.O.; acquisition of data, performed the bioinformatical work, analyzed the clinical data and designed the clinical experiments,

- O.O. and L.O.; interpretation of data, designed the experiments and micronuclei analysis, performed the statistics,

- L.O.; supervised the project, wrote the manuscript.

All authors read and approved the final manuscript

\section{REFERENCES}

1. Abou-Okeil A, El-Shafie A, El Zawahry MM. Ecofriendly laccase-hydrogen peroxide/ ultrasound-assisted bleaching of linen fabrics and its influence on dyeing efficiency. Ultrason Sonochem. 2010 Feb;17(2):383-90.

2. Abdel-Halim ES. An effective redox system for 
bleaching cotton cellulose. Carbohydr Polym. 2012 Sep 1;90(1):316-21.

3. Fenech M. Biomarkers of genetic damage for cancer epidemiology. Toxicology. 2002 Dec 27;181-182:411-6.

4. Wypych G. Handbook of solvents.

5. Tucker JD, Auletta A, Cimino MC, Dearfield KL, Jacobson-Kram D, Tice RR, et al. Sisterchromatid exchange: second report of the GeneTox Program. Mutat Res. 1993 Sep;297(2):10180.

6. Hagmar L, Brøgger A, Hansteen IL, Heim S, Högstedt B, Knudsen L, et al. Cancer risk in humans predicted by increased levels of chromosomal aberrations in lymphocytes: Nordic study group on the health risk of chromosome damage. Cancer Res. 1994 Jun 1;54(11):2919-22.

7. Heddle JA, Cimino MC, Hayashi M, Romagna F, Shelby MD, Tucker JD, et al. Micronuclei as an index of cytogenetic damage: past, present, and future. Environ Mol Mutagen. 1991;18(4):277-91.

8. da Silva Augusto LG, Lieber SR, Ruiz MA, de Souza CA. Micronucleus monitoring to assess human occupational exposure to organochlorides. Environ Mol Mutagen. 1997;29(1):46-52.

9. Costa C, Teixeira JP, Silva S, Roma-Torres J, Coelho P, Gaspar J, et al. Cytogenetic and molecular biomonitoring of a Portuguese population exposed to pesticides. Mutagenesis. 2006 Sep 15;21(5):343-50.

10. Venegas W, Zapata I, Carbonell E, Marcos R. Micronuclei analysis in lymphocytes of pesticide sprayers from Concepción, Chile. Teratog, Carcinog Mutagen. 1998;18(3):123-9.

11. Countryman PI, Heddle JA. The production of micronuclei from chromosome aberrations in irradiated cultures of human lymphocytes. Mutat Res. 1976 Dec;41(2-3):321-32.

12. Fenech M, Morley AA. Measurement of micronuclei in lymphocytes. Mutat Res. 1985 Apr;147(1-2):29-36.

13. Fenech M. Cytokinesis-block micronucleus assay evolves into a "cytome" assay of chromosomal instability, mitotic dysfunction and cell death. Mutat Res. 2006 Aug 30;600 (1-2):5866.

14. Fenech M. The in vitro micronucleus technique. Mutat Res. 2000 Nov 20;455(1-2):8195.

15. Matsuno T, Jung SK, Matsumoto Y, Saito M, Morikawa J. Preferential cytotoxicity to tumor cells of 3,5-diprenyl-4-hydroxycinnamic acid (artepillin C) isolated from propolis. Anticancer Res. 1997 Oct;17(5A):3565-8.

16. Erhan Eroğlu H, Ozkul Y, Tatlisen A, Silici S. Anticarcinogenic and antimitotic effects of Turkish propolis and mitomycin-C on tissue cultures of bladder cancer. Nat Prod Res. 2008;22(12):10606.

17. Lovreglio P, Maffei F, Carrieri M, D'Errico MN, Drago I, Hrelia P, et al. Evaluation of chromosome aberration and micronucleus frequencies in blood lymphocytes of workers exposed to low concentrations of benzene. Mutat Res Genet Toxicol Environ Mutagen. 2014 Aug;770:55-60.

18. White IN, Razvi N, Gibbs AH, Davies AM, Manno M, Zaccaro C, et al. Neoantigen formation and clastogenic action of HCFC-123 and perchloroethylene in human MCL-5 cells. Toxicol Lett. 2001 Oct 15;124(1-3):129-38.

19. Yildırım A, Yıldırım MS. Matbaa Sanayinde Çalışan İşçilerin Bukkal Mukoza Hücrelerinde Mikronükleus ve Binükleotid Siklığının Belirlenmesi. Tıp Araştırmaları Dergisi. 2011;9(1):25-8.

20. Coskun M, Coskun M, Cayir A, Ozdemir O. Frequencies of micronuclei (MNi), nucleoplasmic bridges (NPBs), and nuclear buds (NBUDs) in farmers exposed to pesticides in Çanakkale, Turkey. Environ Int. 2011 Jan;37(1):93-6.

21. Çavuşoğlu K, Yapar K, Yalçın E. Sigara İçenlerde Yanak Mukozası Epitel Hücrelerindeki Toksisitenin Belirlenmesi. Mersin Univ Saglık Bilim Derg. 2008;1(2).

22. Bonassi S, Neri M, Lando C, Ceppi M, Lin Y, Chang WP, et al. Effect of smoking habit on the frequency of micronuclei in human lymphocytes: results from the Human MicroNucleus project. Mutat Res. 2003 Mar;543(2):155-66.

23. Vaglenov AK, Karadjov AG. Micronucleus Frequencies in Bulgarian Control. CEJOEM. 1998 Nov 25;3(3).

24. Richard F, Muleris M, Dutrillaux B. The frequency of micronuclei with $\mathrm{X}$ chromosome increases with age in human females. Mutat Res. 1994 Feb;316(1):1-7.

25. De Méo M, Laget M, Castegnaro M, Duménil G. Genotoxic activity of potassium permanganate in acidic solutions. Mutat Res. 1991 Jul;260(3):295-306.

26. Kaya FF, Topaktaş M. Genotoxic effects of potassium bromate on human peripheral 
lymphocytes in vitro. Mutat Res. 2007 Jan 10;626(1-2):48-52.

27. Lima PDL, Vasconcellos MC, Bahia MO, Montenegro RC, Pessoa CO, Costa-Lotufo LV, et al. Genotoxic and cytotoxic effects of manganese chloride in cultured human lymphocytes treated in different phases of cell cycle. Toxicol In Vitro. 2008 Jun;22(4):1032-7.
28. Baron S, Moss C. Caustic burn caused by potassium permanganate. Arch Dis Child. 2003 Feb;88(2):96.

29. Ong KL, Tan TH, Cheung WL. Potassium permanganate poisoning--a rare cause of fatal self poisoning. J Accid Emerg Med. 1997 Jan;14(1):43-5. 